\title{
KEBIJAKAN PEMBERIAN REMISI BAGI KORUPTOR, SUATU TELAAH KRITIS DARI PERSPEKTIF SOSIOLOGI HUKUM
}

\author{
Edie Toet Hendratno ${ }^{1}$
}

In sociological, granting remission for deeds is very hurt people who are already too long crave for prosperity and fairness. Many parties argued, that the wich memory people's well-being is closely related to rampant corruption in Indonesia. In addition to the many people who expressed his support for the plan of the Ministry of Justice and HUMAN RIGHTS to impose a moratorium on remission for his deeds, it turns out that many are opposed to these policies. One fact that is potentially triggered sharp contradictions in society today is the Government's policy in this regard the Ministry of Law and HUMAN RIGHTS to give the remission for the corruptor. The remissions granted to the convicted person corruption case at the time of independence Memorial and the feast of Eid al-Fitr is already a routine thing. In General, are given on the basis of two long-term remission criteria, namely being of good character over in prison and has been serving at least 6 (six) months. However, corruption, especially applies to the convicted person's special provisions. Article 34, paragraph (3) Government Regulation No. 28, 2006, a new set that can be granted remission after 1/3 (one per three) his criminal sentence. Corruption is a crime unusual (extra ordinary crime), in fact, the United Nations Convention Against Corruption (UNCAC) classifies corruption as a crime of human rights (human rights crime) and crimes against humanity (crime against humanity). The maximum penalty should be given the right deeds, without remission. They've cost the State money that led to losses for millions of people, so it is not deserved privileges. It is precisely the right deeds should be made poor and that need to be social sanctions. It is not the place to the prison of vengeance. However, the prison is also not a place to enjoy the privileges of criminals including got remission. Punish one's deeds to its full potential not only of learning for the convicted person itself, but also be a lesson for millions of people outside the prison walls in order to undo the intention to rob the State money. Removal and/or tighten the granting of remission for the corruptor is a decent policy to be applied.

Keywords: policy of granting remission, corrupt, moratorium

\begin{abstract}
Abstrak
Secara sosiologis, pemberian remisi untuk narapidana sesungguhnya sangat melukai masyarakat yang telah lama menanti kesejahteraan dan keadilan. Banyak pihak berpendapat, merosotnya kesejahteraan masyarakat berkaitan

\footnotetext{
${ }^{1}$ Penulis adalah Staf Pengajar di FHUI dan FH Universitas Pancasila. Alamat kontak: mr.yogasatria@gmail.com.
} 
dengan korupsi yang merajalela di Indonesia. Di tambah lagi, banyak pihak yang mendukung rencana Kementerian Hukum dan HAM menetapkan moratorium remisi bagi narapidana. Hal itu menunjukkan banyak pihak yang menentang kebijakan remisi tersebut. Pemberian remisi oleh Kementerian Hukum dan HAM adalah fakta yang dapat menjadi pemicu pertentanganpertentangan dalam masyarakat dewasa ini. Remisi yang diberikan kepada narapidana kasus korupsi pada peringatan Hari Kemerdekaan dan Hari Raya Idul Fitri telah menjadi sesuatu yang rutin. Secara umum, remisi itu diberikan berdasar pada dua kriteria remisi jangka panjang, yaitu berkelakuan baik selama di penjara dan telah menjalani pemidanaan setidaknya enam bulan. Pasal 34 paragraf (3) Peraturan Pemerintah No. 28 tahun 2006 menentukan bahwa remisi dapat diberikan setelah narapidana menjalani sepertiga masa tahanan. Korupsi adalah kejahatan luar biasa sebagaimana United Nations Convention Against Corruption (UNCAC) mengklasifikasikan korupsi sebagai kejahatan HAM atau kejahatan terhadap kemanusiaan. Pemidanaan maksimal semestinya diberikan kepada pelakunya, tanpa remisi. Mereka telah merugikan keuangan Negara yang berujung pada kerugian jutaan warga Negara, sehingga mereka tidak boleh diistimewakan. Mereka semestinya dimiskinkan dan mendapat sanksi sosial, bukan mendapat keistimewaan selama di penjara. Pemidanaan tersebut harusnya tidak hanya menjadi pelajaran bagi si narapidana, tetapi juga menjadi pelajaran bagi jutaan warga negara di luar tembok penjara. Pencabutan dan/atau pengetatan pemberian remisi untuk narapidana korupsi adalah kebijakan yang tepat untuk diterapkan.

Kata kunci: kebijakan pemberian remisi, korup, moratorium

\section{Pendahuluan}

\section{Latar Belakang Permasalahan}

Dalam pidato pada peringatan Hari Anti Korupsi Sedunia tahun 2013, Presiden Yudhoyono mengatakan bahwa pemberantasan korupsi merupakan agenda berkelanjutan, bukan proses sekali jadi. "Saya sebut never ending goal, unfinished agenda, tidak akan pernah berhenti. Jadi, jangan kita berangan-angan, lima tahun lagi, sepuluh tahun lagi, Indonesia benar-benar sudah bebas dari ancaman korupsi," katanya. ${ }^{2}$

Ironinya, semangat itu seolah-olah padam dengan fakta yang ada. Sejumlah terpidana korupsi yang sedang menjalani masa hukuman, justru mendapatkan remisi dan pembebasan bersyarat dari Kementerian Hukum dan HAM. Koruptor Anggodo Widjojo mendapat remisi sebanyak 29

${ }^{2}$ KPK Rekomendasikan Tak Berikan Remisi Bagi Koruptor, <http://www.kpk.com>, diakses Kamis 20 November 2014. 
bulan 10 hari dan kini, Kemenkumham tengah memproses pembebasan bersyaratnya ${ }^{3}$.

Wakil Ketua KPK Busyro Muqoddas mengatakan, remisi ${ }^{4}$ dan pembebasan bersyarat bagi korupstor, selain melukai rasa keadilan hukum, juga menunjukkan pemerintah yang tidak sensitive terhadap semangat pemberantasan koruspi. Lebih dari itu, "kejahatan korupsi yang luar biasa, justru dihukum dengan tidak luar biasa. Ini menyedihkan," kata Busyro.

Busyro menilai keputusan pemerintah memberikan remisi atau membebaskan seorang koruptor, tidak mempertimbangkan empati sosial. "Kalau empati sosial dimaknai, remisi itu tidak akan diberikan," katanya. Karena itu, "Sikap KPK menolak pemberian remisi dan mendesak pemerintah untuk membatalkannya".

${ }^{3}$ Ibid.

${ }^{4}$ Remisi adalah pengurangan masa hukuman yang didasarkan ketentuan perundangundangan yang berlaku di Indonesia. Menurut Pasal 1 ayat (1) Keputusan Presiden Republik Indonesia No. 174 Tahun 1999, remisi adalah pengurangan masa pidana yang diberikan kepada narapidana dan anak pidana yang telah berkelakuan baik selama menjalani pidana. Menurut Pasal 1 ayat (6) Peraturan Pemerintah No. 32 Tahun 1999, remisi adalah pengurangan masa pidana yang diberikan kepada narapidana dan anak pidana yang telah memenuhi syarat-syarat yang ditentukan dalam peraturan perundang-undangan. Menurut Pasal 34 Peraturan Pemerintah No. 99 Tahun 1999 sebagai berikut:

a. Setiap narapidana dan anak pidana berhak mendapatkan remisi.

b. Remisi sebagaimana dimaksud pada ayat (1) dapat diberikan kepada narapidana dan anak pidana yang telah memenuhi syarat:

1) berkelakuan baik; dan

2) telah menjalani masa pidana lebih dari 6 (enam) bulan.

Persyaratan berkelakuan baik sebagaimana dimaksud pada ayat (2) huruf a dibuktikan dengan a) tidak sedang menjalani hukuman disiplin dalam kurun 6 (enam) bulan terakhir, terhitung sebelum tanggal pemberian remisi; dan b) telah mengikuti program Pembinaan yang diselenggarakan LAPAS dengan predikat baik. Lihat "Remisi", <http://www.id.wikipedia.org/ wiki/REmisi>, diakses Kamis 20 November 2014.

5 Komisioner Komisi Pemberantasan Korupsi mengaku kecewa lantaran Kementerian Hukum dan Hak Asasi Manusia dengan mudah memberikan remisi dan pembebasan bersyarat bagi para terpidana korupsi. Juru bicara KPK, Johan Budi Sapto Prabowo, mengatakan kemudahan ini bisa memunculkan persepsi di kalangan koruptor. Mereka bisa-bisa menggampangkan sanksi yang dijatuhkan meski komisi antirasuah itu menuntut hukuman yang berat. "Toh, akhirnya percuma saja keberadaan KPK ini. Dalam konteks pembebasan bersyarat, tidak digubris juga. Ya, biarin aja KPK mau ngapain," kata Johan di kantornya, Jumat, 19 September 2014. Soalnya, ketika sudah divonis dengan kekuatan hukum tetap, terdakwa korupsi menjadi kewenangan kementerian hukum. Johan melanjutkan, KPK menuntut presiden terpilih Joko Widodo giat mengkampanyekan pemberantasan korupsi sesuai dengan janjinya. "Kami akan tagih itu, apakah presiden yang baru itu menjalankan janjijanji kampanyenya," ujar Johan. Kementerian Hukum sedang mengkaji pemberian pembebasan bersyarat bagi terpidana kasus percobaan suap terhadap pimpinan dan penyidik KPK Anggodo Widjojo. Kementerian hukum menilai adik Anggoro Widjojo, terdakwa kasus suap pengadaan sistem komunikasi radio terpadu (SKRT) di Departemen Kehutanan, itu berhak memperoleh remisi umum dan remisi khusus selama 2010-2014 sebanyak 24 bulan 10 hari. Di Pengadilan 
Seakan tak mendengar kritikan publik, pemerintah kembali mengobral remisi (potongan masa tahanan) bagi koruptor. Sebanyak 10.532 narapidana di 20-an penjara di Jawa Barat kembali diusulkan mendapatkan remisi pada hari Lebaran. Usulan pemotongan masa hukuman itu berlaku pula untuk para koruptor di Penjara Sukamiskin Bandung.

Ibnu Chuldun, Kepala Divisi Pemasyarakatan Kementerian Hukum dan HAM Jawa Barat, mengatakan ada 137 koruptor di Sukamiskin dan penjara lain yang diusulkan mendapat remisi Lebaran 1445 Hijriah. "Misalnya Muhammad Nazaruddin diusulkan mendapat remisi khusus 1 bulan dan remisi umum 3 bulan. Gayus Tambunan diusulkan mendapat remisi 1 bulan 15 hari", kata Ibnu saat dihubungi, Rabu, 23 Juli 2014. ${ }^{6}$

Nama lain yang diusulkan adalah bekas Kepala Bareskrim Susno Duadji yang dibui di Penjara Bogor. Susno dipertimbangkan mendapat remisi khusus 1 bulan dan remisi umum 2 bulan. Adapun dari total 10.532 calon penerima remisi, terpidana kasus pidana umum berjumlah 7.309 orang, sedangkan kasus pidana khusus 3.223 orang. "Remisi akan diberikan resmi pada hari Lebaran", kata Ibnu.

Seperti diketahui, Gayus adalah terpidana 7 tahun penjara dalam kasus korupsi perpajakan. Tahun lalu, Gayus sempat diusulkan mendapat remisi Hari Kemerdekaan selama 4 bulan namun kemudian dibatalkan. Sedangkan Nazaruddin terpidana 7 tahun penjara dalam kasus korupsi dana pembangunan Wisma Atlet Hambalang. Nazar sempat dianggap belum layak mendapat remisi karena baru divonis pada awal tahun ini. ${ }^{7}$

Kebijakan remisi semakin membuat publik ragu akan niat pemerintah untuk membumi-hanguskan koruptor. Bagaimana tidak, di satu sisi Presiden SBY selalu berpidato akan memimpin pemberantasan

Tindak Pidana Korupsi Jakarta, Anggoro divonis 5 tahun penjara karena terbukti mencoba menyuap pimpinan dan penyidik KPK sebesar Rp 5 miliar lebir. Upaya itu dia lakukan guna menggagalkan penyidikan kasus korupsi SKRT di Departemen Kehutanan yang melibatkan kakaknya, yang saat itu masih buron. Mahkamah Agung menolak permohonan banding Anggodo di tingkat kasasi dan justru memperberat hukumannya menjadi 10 tahun penjara dengan denda $\mathrm{Rp} 250$ juta subsider 5 bulan kurungan. Anggodo terbukti dengan sengaja mencegah, merintangi, atau menggagalkan penyidikan, penuntutan, dan pemeriksaan di sidang Pengadilan Tindak Pidana Korupsi sebagaimana diatur dalam Pasal 21 Undang-Undang Nomor 31 Tahun 1999. Sebelumnya, Kementerian Hukum memberikan pembebasan bersyarat untuk lima terpidana korupsi. Di antaranya terpidana kasus suap Bupati Buol, Hartati Murdaya Poo; dan terpidana kasus korupsi dana penyesuaian infrastruktur daerah, Fahd El Fouz. Padahal, KPK sudah menolak permohonan menjadikan keduanya justice collaborator. Dalam kasus remisi Anggodo, KPK sudah mengirimkan penolakan kepada Kementerian Hukum. Lihat KPK Kecewa Kementerian Hukum Obral Remisi Bagi Koruptor, 〈http://www.tempo.com>, diakses Kamis 20 November 2014.

${ }^{6}$ Tiga Koruptor Diusulkan Dapat Remisi, <https://www.id.berita.yahoo.com/tigakoruptor-ini-diusulkan-dapat-remisi-lagi>, diakses Kamis 20 November 2014.

7 Moratorium Remisi Terhadap Koruptor Jangan Hanya Wacana, <http://www.news.okezone.com/ read/2011/10/31/339/523022/moratorium>, diakses Kamis 20 November 2014. 
korupsi dan bertindak tegas terhadap koruptor. Sementara di sisi lain, Menteri Hukum dan HAM selalu mengobral remisi dan pembebasan bersyarat bagi koruptor. Bagi rakyat banyak, kebijakan tersebut jelas melukai rasa keadilan $^{8}$

Alasan yang selalu digunakan pemerintah untuk pemberian remisi ini sangatlah naif. Pemerintah selalu bersembunyi dibalik aturan hukum positif, bahwa peraturan perundang-undangan tidak melarang pemberian remisi bagi koruptor. Memang benar, bahwa undang-undang mengizinkan pemberian remisi bagi narapidana sebagaimana diatur dalam Undang Undang Nomor 12 tahun 1995 tentang Pemasyarakatan.

Pasal 14 Undang Undang Nomor 12 tahun 1995 tentang Pemasyarakatan menyebutkan, bahwa salah satu hak terpidana adalah mendapatkan pengurangan masa pidana (remisi). Teknisnya, diatur lebih lanjut dalam Peraturan Pemerintah Nomor. 28 tahun 2006 tentang Perubahan Peraturan Pemerintah Nomor 32 tahun 1999 tentang Syarat dan Tata Cara Pelaksanaan Hak Warga Binaan Pemasyarakatan.

Indonesia memang sudah lama dikenal sebagai surga bagi para koruptor. Mereka yang mengkorupsi uang negara sampai puluhan milyar rupiah hanya dijatuhi sanksi pidana yang ringan, bahkan ada yang dibebaskan oleh hakim. Bagi terpidana kasus korupsi yang dipenjarapun, sejumlah keistimewaan dan berbagai fasilitas menantinya. ${ }^{9}$

Korupsi sudah berlangsung lama, sejak jaman Mesir Kuno dan terjadi diberbagai negara tak terkecuali di negara-negara maju sekalipun. Di negara Amerika Serikat sendiri yang sudah begitu maju masih ada praktek korupsi, sebaliknya pada masyarakat yang primitif di mana ikatan-ikatan sosial masih sangat kuat dan kontrol sosial yang efektif, korupsi relatif jarang terjadi. ${ }^{10}$

Korupsi pada prinsipnya bukan saja menyengsarakan kehidupan rakyat banyak, akan tetapi juga sudah merupakan kejahatan yang luar biasa (extra ordinary crime) yang menindas hak asasi rakyat dan menghambat pembangunan nasional. Oleh karena itu pemberian remisi bagi para koruptor sangat bertentangan dengan nilai-nilai keadilan masyarakat.

Pemberian remisi secara yuridis pada hakikatnya tidak bertentangan dengan peraturan perundang-undangan yang berlaku, apalagi Indonesia adalah negara yang bermazhab positivisme yang berpandangan bahwa

\footnotetext{
8 Penghapusan Remisi Bagi Koruptor Belum Cukup, <http://www.nasional.kompas.com>, diakses Kamis 20 November 2014.

${ }^{9}$ Pemberian Remisi Untuk Koruptor Diperketat, <http://www.metrotvnews.com>, diakses Kamis 27 November 2014.
}

${ }^{10}$ Edward L. Glaeser and Claudia Goldin, eds, "Corruption and Reform: Lessons from America's Economic History”, (University of Chicago Press, 2006), p. 386 dan Erika Revida. Korupsi Di Indonesia: Masalah dan Solusinya. Makalah, Fakultas Ilmu Sosial dan Ilmu Politik Universitas Sumatera Utara. Medan, 2003, hal. 1. 
hukum itu adalah undang-undang. Bagi mazhab positivisme, keadilan dan kebenaran didasarkan pada bunyi dari peraturan perundangundangan. Mazhab positivisme memang sangat legalistik, empirik dan yang terpenting adanya kepastian hukum. Positivisme memang tidak memberikan ruang buat rasa kemanusiaan dan bahkan pada moralitas. ${ }^{11}$

Secara sosiologis, pemberian remisi bagi koruptor sangat melukai hati rakyat yang sudah terlalu lama mendambakan kesejahteraan dan keadilan. Banyak pihak yang berpendapat, bahwa terhambatnya kesejahteraan rakyat berkaitan erat dengan maraknya korupsi di Indonesia. $^{12}$

Di samping banyak pihak yang menyatakan dukungannya terhadap rencana Menteri Hukum dan HAM untuk memberlakukan moratorium remisi bagi para koruptor, ternyata banyak pula yang menentang kebijakan tersebut.

Kalau ada berbagai pihak yang berpandangan, bahwa koruptor tidak layak mendapatkan remisi, boleh jadi karena sudah begitu kesal dengan apa yang telah dilakukan oleh para koruptor. Akan tetapi, saat Menteri Hukum dan HAM akan memberlakukan moratorium atau penghentian sementara remisi bagi terpidana korupsi, justru banyak pengamat hukum yang tidak setuju. Ada yang menilai moratorium tersebut melanggar hukum, melanggar HAM dan bahkan menuduh Menteri Hukum dan HAM serta Wakil Menterinya bertindak sewenang-wenang. ${ }^{13}$

Di tengah maraknya pro dan kontra tentang rencana pemerintah untuk memberikan remisi bagi koruptor, Wakil Menteri Hukum dan HAM menyatakan, bahwa kebijakan pemerintah untuk memberikan remisi bukan untuk membebaskan terpidana kasus korupsi akan tetapi memperketat persyaratannya. ${ }^{14}$

Untuk mengetahui lebih jauh kebijakan remisi bagi para koruptor, tulisan ini akan membahas tentang "Kebijakan Pemberian Remisi Bagi Koruptor (Suatu Telaah Kritis Dari Perspektif Sosiologi Hukum)”.

\section{Pokok Permasalahan}

Dengan mengacu pada latar belakang permasalahan sebagaimana telah diuraikan di atas, maka yang menjadi pokok permasalahan adalah:

1. Bagaimana kebijakan pemberian remisi bagi koruptor bila ditelaah dari aspek sosiologi hukum?

11 Pemberlakuan Moratorium Remisi Bagi Pelaku Tindak Pidana Korupsi, <http://www.arya-sosman.blogspot.com>, hal. 1, diakses Jumat 28 November 2014.

${ }^{12}$ Ibid., hal. 5.

13 Kemenkum HAM Berlakukan Moratorium Remisi Bagi Koruptor. <http://www.berita.liputan6. com>, diakses Jumat 28 November 2014.

${ }^{14}$ Ibid. 
2. Mengapa terjadi pro dan kontra tentang kebijakan pemberian remisi bagi koruptor?

\section{Pembahasan}

\section{Kebijakan Pemberian Remisi Bagi Koruptor (Telaah Kritis dari Aspek Sosiologi Hukum)}

Perspektif hukum dalam konteks interaksi sosial dapat mengalami perubahan dalam pengaturan dan penerapan. Hukum yang diharapkan bisa memecahkan masalah secara adil dan bermanfaat bagi kehidupan masyarakat, dalam kenyataan bisa berubah ke arah pengaturan dan penerapan hukuman bagi siapa yang kuat dialah yang menang. Inilah yang mewarnai penerapan hukum dalam konteks sosial. ${ }^{15}$

Perubahan dalam penerapan hukum merupakan fenomena yang berlangsung secara alami, karena itu perlu dipahami apa yang sebenarnya terjadi, mengapa hal itu bisa terjadi, dan bagaimana penerapan hukum itu berlangsung. Diskursus tentang penerapan hukum dalam masyarakat merupakan instrumen yang inheren dalam kehidupan sosial, tetapi dalam kenyataan hal itu terkesampingkan. Karena itu masyarakat menuntut perlunya tatanan hukum baru guna menjaga ketertiban sosial. ${ }^{16}$

Studi tentang perubahan hukum sangat lekat dengan cara mengarahkan peran manusia sebagaimana yang diharapkan. Di sini posisi hukum menjadi multi dimensi dalam kehidupan manusia, oleh karena itu dalam perubahan hukum juga menyangkut secara langsung terhadap keperluan ketertiban sosial yang meliputi nilai dan norma sosial, sistem kemasyarakatan, kebiasaan dan relasi sosial yang belum maupun yang sudah mapan, dan sistem kelembagaan sehingga meskipun ada pergeseran tetapi pranata hukum diharapkan tetap terjaga. ${ }^{17}$

Perubahan hukum dalam kehidupan sosial merupakan suatu kenyataan yang terjadi dalam upaya manusia membangun kehidupannya. Perubahan hukum bisa berbentuk evolusi, transformasi ataupun revolusi tergantung dari dinamikanya. Perubahan hukum juga bisa terjadi secara gradual atau radical.

Perubahan hukum dan akibatnya terhadap kondisi masyarakat telah menjadi fakta dalam kehidupan manusia, sebagai reaksi atas rangsangan dari luar maupun dari dalam masyarakat sendiri. Akibat dari perubahan

15 Bambang Widodo Umar, "Paradigma Sosiologi Hukum", (Jakarta: Universitas Indonesia, 2009), hal. 1.

16 Adam Podgorecki, "A Sociological Theory of Law", (Milano: Dott.A.Giuffre Editore, 1991), p. 156.

hal. 10 .

17 Alvin S. Johnson, “Sosiologi Hukum.”, (Jakarta: Penerbit Rineka Cipta, 2007), 
itu terhadap kehidupan manusia menimbulkan efek positif maupun negatif.

Selain perubahan hukum, dikenal juga perkembangan hukum, yaitu pembenahan hukum yang ditujukan untuk mencapai kemajuan atau perbaikan keadaan hidup masyarakat. Dengan perkataan lain, perkembangan hukum berkaitan dengan rekayasa yang dilakukan melalui penggunaan ilmu-ilmu hukum untuk memperbaiki tatanan sosial agar dengan perbaikan itu manusia dapat hidup lebih layak sesuai martabatnya ${ }^{18}$

Bagi masyarakat tertentu, perkembangan hukum bisa dianggap sebagai pemicu terjadinya kontradiksi yang menajam dan keras bahkan menjadi penyebab timbulnya kerusuhan sosial karena implementasinya tidak adil. Pandangan ini didasarkan pada fakta yang terjadi di sekitar kehidupan manusia, bahwa instrumen hukum tidak bekerja secara memuaskan dan justru memicu konflik yang membesar dan destruktif.

Melalui sosiologi hukum, perkembangan yang terjadi dalam masyarakat bisa dikenali efek-efek sosial dari penerapan hukum. Selain itu untuk memecahkan masalah hukum, teknik-teknik sosiologi dan metode-metode evaluasinya memiliki nilai cognitif sebagai penuntun jika fenomena hukum didasarkan pada asumsi-asumsi teori yang sudah diketahui. $^{19}$

Salah satu fakta yang berpotensi untuk memicu terjadinya kontradiksi yang tajam di masyarakat dewasa ini adalah kebijakan pemerintah dalam hal ini Kementerian Hukum dan HAM untuk memberikan remisi bagi para koruptor. Remisi yang diberikan kepada terpidana kasus korupsi pada saat peringatan kemerdekaan dan hari raya Idul Fitri sudah merupakan hal yang rutin.

Secara umum, remisi tersebut diberikan berdasarkan dua syarat, yakni berkelakuan baik selama di penjara dan telah menjalani hukuman minimal selama 6 (enam) bulan. Namun, terkhusus bagi terpidana korupsi, berlaku ketentuan khusus. Pasal 34 ayat (3) Peraturan Pemerintah Nomor 28 tahun 2006 mengatur, bahwa remisi baru dapat diberikan setelah menjalani $1 / 3$ (satu per tiga) masa hukuman pidana. Ketentuan ini juga berlaku untuk terpidana kasus terorisme, narkotika, kejahatan terhadap keamanan negara, kejahatan hak asasi manusia yang berat, dan kejahatan transnasional terorganisasi lainnya.

Walaupun pemberian remisi dibenarkan, pertanyaannya adalah apakah remisi wajib diberikan? Jawabannya tidak! Tidak ada kewajiban bagi pemerintah memberikan remisi bagi koruptor. Malah sebaliknya, koruptor harusnya tidak perlu mendapatkan remisi. Koruptor tidaklah sama dengan para terpidana kejahatan kriminal biasa.

${ }^{18}$ L.M Friedman, "The Legal System: A Society Science Perspective”, (New York: Russel Sage Foundation, 1975), p. 23.

${ }^{19}$ Niklas Luhmann, “A Sociological Theory of Law”, (London: Routledge \& Kegan Paul, 1985), p. 55. 
Korupsi $^{20}$ adalah kejahatan kriminal luar biasa (extra ordinary crime), bahkan, United Nations Convention Against Corruption (UNCAC) mengklasifikasikan korupsi sebagai kejahatan hak asasi manusia (human rights crime) dan kejahatan kemanusiaan (crime against humanity). ${ }^{21}$

Pada kasus tindak pidana biasa, yang dirugikan hanya satu individu saja. Namun, korupsi memiliki dampak merugikan dalam skala yang sangat luas. Sehingga, cara-cara yang luar biasa patut diterapkan kepada koruptor. Salah satu bentuknya adalah dengan menghapus remisi bagi koruptor.

Koruptor harusnya diberi hukuman maksimal, tanpa remisi. Mereka sudah mengeruk uang negara yang menimbulkan kerugian bagi jutaan rakyat, sehingga tidak pantas mendapat keistimewaan. Justru koruptor harusnya dimiskinkan dan kalau perlu diberi sanksi sosial.

Memang penjara bukanlah tempat untuk balas dendam. Namun, penjara juga bukan tempat seorang penjahat boleh menikmati keistimewaan termasuk mendapat remisi. Menghukum seseorang

${ }^{20}$ Korupsi atau rasuah (bahasa Latin: corruptio dari kata kerja corrumpere yang bermakna busuk, rusak, menggoyahkan, memutarbalik, menyogok) adalah tindakan pejabat publik, baik politisi maupun pegawai negeri, serta pihak lain yang terlibat dalam tindakan itu yang secara tidak wajar dan tidak legal menyalahgunakan kepercayaan publik yang dikuasakan kepada mereka untuk mendapatkan keuntungan sepihak. Dari sudut pandang hukum, tindak pidana korupsi secara garis besar memenuhi unsur-unsur sebagai berikut:

a. Perbuatan melawan hukum,

b. Penyalahgunaan kewenangan, kesempatan, atau sarana,

c. Memperkaya diri sendiri, orang lain, atau korporasi, dan

d. Merugikan keuangan negara atau perekonomian negara.

Jenis tindak pidana korupsi di antaranya, namun bukan semuanya, adalah:

a. Memberi atau menerima hadiah atau janji (penyuapan),

b. Penggelapan dalam jabatan,

c. Pemerasan dalam jabatan,

d. Ikut serta dalam pengadaan (bagi pegawai negeri/penyelenggara negara), dan

e. Menerima gratifikasi (bagi pegawai negeri/penyelenggara negara).

Dalam arti yang luas, korupsi atau korupsi politis adalah penyalahgunaan jabatan resmi untuk keuntungan pribadi. Semua bentuk pemerintah|pemerintahan rentan korupsi dalam prakteknya. Beratnya korupsi berbeda-beda, dari yang paling ringan dalam bentuk penggunaan pengaruh dan dukungan untuk memberi dan menerima pertolongan, sampai dengan korupsi berat yang diresmikan, dan sebagainya. Titik ujung korupsi adalah kleptokrasi, yang arti harafiahnya pemerintahan oleh para pencuri, dimana pura-pura bertindak jujur pun tidak ada sama sekali. Korupsi yang muncul di bidang politik dan birokrasi bisa berbentuk sepele atau berat, terorganisasi atau tidak. Walau korupsi sering memudahkan kegiatan kriminal seperti penjualan narkotika, pencucian uang, dan prostitusi, korupsi itu sendiri tidak terbatas dalam hal-hal ini saja. Untuk mempelajari masalah ini dan membuat solusinya, sangat penting untuk membedakan antara korupsi dan kejahatan. Tergantung dari negaranya atau wilayah hukumnya, ada perbedaan antara yang dianggap korupsi atau tidak. Sebagai contoh, pendanaan partai politik ada yang legal di satu tempat namun ada juga yang tidak legal di tempat lain. Lihat Korupsi, <http://www.wikipedia.com>, diakses Jumat 28 November 2014.

${ }^{21}$ Remisi Untuk Koruptor?, <http://www.ocemadril.wordpress.com>, diakses Jumat 28 November 2014. 
koruptor secara maksimal bukan hanya pembelajaran bagi terpidana itu sendiri, melainkan juga menjadi pelajaran bagi jutaan orang di luar tembok penjara agar mengurungkan niat merampok uang negara.

Selain melukai rasa keadilan masyarakat, pemberian remisi juga rentan dipermainkan oleh mafia hukum. Pemberian remisi memang hak pemerintah. Tapi apakah ada jaminan bahwa pemberian remisi tidak akan disalahgunakan? Siapa yang bisa mengontrol pemberian remisi itu?

Banyak pihak yang khawatir diskresi pemerintah yang tidak terkontrol dalam pemberian remisi ini rentan disalahgunakan. Fasilitas remisi ini potensial dijadikan proyek oleh aparat pemerintah dan para mafia hukum.

Mudahnya koruptor mendapatkan remisi merupakan indikasi awal. Dugaan tersebut diperkuat dengan maraknya praktik suap di penjara. Sebagaimana modus mafia penjara yang terungkap selama ini, bahwa ada praktik suap-menyuap antara terpidana dengan petugas penjara, misal kasus suap Gayus Tambunan ke petugas rumah tahanan Mako Brimob, kasus sel mewah Artalyta Suryani dan joki narapidana Kasiyem di Bojonegoro. Selain itu, berbagai keanehan dalam pemberian remisi selama ini menunjukkan bahwa ada yang bermasalah dalam kebijakan tersebut.

Protes publik dan rentannya praktik mafia hukum dalam pemberian remisi ini, mestinya mampu membuat Menteri Hukum dan HAM menahan diri untuk tidak memberikan remisi untuk koruptor. Jika tidak, maka sulit rasanya untuk menyatakan, bahwa pemerintah serius mendukung upaya pemberantasan korupsi. Komitmen politik pemerintah akan dipertanyakan.

Fakta pemberian remisi untuk koruptor memberi penjelasan kepada rakyat, bahwa perang melawan korupsi tidak didukung oleh kemauan politik yang kuat dan sungguh-sungguh. Kemauan politik yang ambivalen itu, membuat sistem hukum Indonesia menjadi sangat kompromistis terhadap koruptor. Sudah mendapat hukum ringan, para koruptorpun diberi hak mendapatkan diskon hukuman bernama remisi itu.

Banyaknya kasus korupsi di Indonesia dengan berbagai modus operandinya mengingatkan, bahwa korupsi semakin kronis. Bahkan modus operandi yang dilakukan sudah sangat berkualitas dan sistematis dengan melibatkan pejabat penegak hukum pula. Apabila dibiarkan dan tidak segera diberantas, akan menjadi apa Republik ini nantinya?

Emanuel Kant menyatakan, bahwa kalau keadilan sudah tidak diperoleh berarti sudah tidak ada lagi alasan untuk bertahan di muka bumi ini. Berkenaan dengan negara, mungkin kelangsungan hidup suatu negara akan menjadi pertaruhan. ${ }^{22}$

\footnotetext{
${ }^{22}$ R. Banakar and M. Travers, "Law, Sociology and Method in Theory and Method in Socio Legal Research", (Oxford: Hart Publishing, 2005), p. 11.
} 
Korupsi adalah kejahatan luar biasa yang tentunya membutuhkan upaya penyelesaian yang luar biasa pula. Friedmann mengungkapkan, bahwa bagaimanapun penegakan hukum suatu bangsa mutlak ditentukan oleh substansi hukum, struktur hukum dan budaya hukum negara setempat. $^{23}$

Secara sosiologis, perilaku koruptor bertentangan dengan fungsi hukum sebagai sosial kontrol yang merupakan aspek yuridis normatif dari kehidupan masyarakat atau dapat disebut sebagai pemberi definisi dari tingkah laku menyimpang serta akibat-akibatnya seperti laranganlarangan, perintah-perintah, pemidanaan dan ganti rugi.

Sebagai alat pengendalian sosial, hukum dianggap berfungsi untuk menetapkan tingkah laku yang baik dan tidak baik atau perilaku menyimpang dari hukum, dan sanksi hukum terhadap orang yang mempunyai perilaku yang tidak baik.

Manfaat yang dapat diperoleh dari kontrol sosial terhadap penyimpangan perilaku seseorang yang terjadi dalam masyarakat adalah pranata hukum berfungsi bersama pranata lainnya dalam melakukan pengendalian sosial.

Selain itu, dapat dikemukakan bahwa pranata hukum itu pasif, yaitu hukum menyesuaikan diri dengan kenyataan sosial dalam masyarakat. Oleh karena itu, terlaksana atau tidaknya fungsi hukum sebagai alat pengendalian sosial sangat ditentukan oleh faktor aturan hukum dan faktor penegak hukum. ${ }^{24}$ Berlakunya hukum di tengah-tengah masyarakat pada hakikatnya mengemban tujuan untuk mewujudkan keadilan, kepastian hukum dan kemanfaatan sosial bagi masyarakatnya.

Dalam kacamata sosiologi hukum yang digunakan oleh Alvin Johnson tentang eksistensi dan peran hukum ditegaskan, bahwa dalam kehidupan sosial yang nyata, hukum mempunyai daya mengatur hanya jika sudah dipersatukan dalam suatu kerangka hukum, lebih-lebih dalam satu sistem hukum. ${ }^{25}$

Remisi memang hak terpidana, akan tetapi pemberian remisi tetap memerlukan kebijakan negara. Artinya, negara bisa memberikan, tetapi juga boleh membatasinya dengan klausul yang ditentukan oleh negara. Pasal 28J ayat (2) Undang Undang Dasar 1945 menyatakan, bahwa dalam menjalankan hak dan kebebasan, setiap orang wajib tunduk pada pembatasan yang ditetapkan dengan undang-undang.

Tujuannya adalah untuk menjamin pengakuan serta penghormatan atas hak dan kebebasan orang lain, dan untuk memenuhi tuntutan yang 2009), hal. 37. 1999), p. 291.

${ }^{24}$ Emile Durkheim, "Law in Moral Domain”, (New Haven: Yale University Press,

${ }^{25}$ Alvin S. Johnson. Op. Cit., hal. 191. 
adil sesuai dengan pertimbangan moral, nilai-nilai agama, keamanan, dan ketertiban umum dalam masyarakat demokratis.

Apabila negara melalui Menteri Hukum dan HAM memperketat syarat pemberian remisi dan pembebasan bersyarat bagi koruptor, tentu bukan melanggar hak asasi manusia. Hak-hak koruptor secara yuridis adalah hak yang bisa dibatasi, bahkan juga tersurat dalam undang-undang pemasyarakatan bahwa syarat dan tata cara pemberian remisi diatur (bisa dibatasi) dengan peraturan pemerintah. Realitas selama ini, justru koruptor sering mendapat perlakuan istimewa dalam pemberian remisi dengan meringankan syaratnya.

Rakyat yang dirugikan dan disengsarakan oleh para koruptor berharap agar koruptor dijatuhi hukuman berat. Mencederai rasa keadilan masyarakat yang sering dijadikan alasan agar koruptor tidak diberi toleransi, memang bisa diperdebatkan secara hukum karena ukurannya terlalu abstrak. Tetapi aspek itulah yang senantiasa diperjuangkan sebagai keadilan substansial yang harus ditonjolkan dibandingkan keadilan prosedural.

Menghukum koruptor secara maksimal bukan hanya pembelajaran bagi terpidana itu sendiri, melainkan juga terutama bagi jutaan orang di luar tembok penjara agar mengurungkan niat merampok uang negara. Hukuman penjara bagi koruptor tidak akan menimbulkan efek jera apabila berbagai kemudahan terus diberikan. Apalagi selama ini pengadilan selalu memberikan hukuman yang ringan bagi koruptor dan bahkan membebaskannya. Dengan menerima remisi, koruptor tidak perlu waktu lama untuk menghirup udara bebas kembali.

Oleh karena itu, penghapusan dan/atau memperketat pemberian remisi bagi koruptor merupakan kebijakan yang layak untuk diterapkan. Alasan kelakuan baik selama berada di penjara tidak dapat digunakan untuk memberikan remisi. Betapapun para koruptor memperlihatkan kelakuan baik selama di penjara, alasan tersebut tidak dapat menghapus kejahatan korupsi yang telah dilakukannya. Apalagi biasanya motif mereka berkelakuan baik di penjara hanya untuk memperoleh remisi.

Moratorium remisi bagi koruptor dari sudut pandang aliran sosiologi hukum menurut Max Weber dapat terbentuk dengan dua cara, yaitu: ${ }^{26}$

1) Muncul secara bertahap;

2) Diciptakan secara sengaja.

Pada tahap yang pertama (hukum muncul secara bertahap), orang mulai membuat cara pemakaian baru dari aturan-aturan yang ada sehingga menghasilkan pergeseran bertahap dalam arti aturan-aturan tersebut. Pada tahap yang kedua (diciptakan secara sengaja), pembentukan hukum baru dilakukan melalui paksaan dari atas dan ini merupakan suatu penyimpangan dalam pembentukan hukum baru.

\footnotetext{
${ }^{26}$ Adam Podgorecki dan Christopher J. Whelan "Pendekatan Sosiologi Terhadap Hukum”, (Jakarta: Bina Aksara, 1987), hal. 44.
} 
Secara umum teori-teori sosiologi hukum berkaitan erat dengan 1) pembuatan hukum, 2) faktor-faktor yang berpengaruh terhadap produk hukum, 3) pelanggaran hukum yang meliputi siapa pelakunya, mengapa sampai terjadi, serta bagaimana pelaksanaannya, 4) reaksi terhadap pelanggaran hukum melalui proses peradilan atau reaksi masyarakat. ${ }^{27}$

\section{Pro Kontra Kebijakan Remisi Bagi Koruptor}

Remisi bagi para koruptor secara yuridis diatur khusus berdasarkan ketentuan Pasal 34 ayat (3) Peraturan Pemerintah Nomor 28 tahun 2006 tentang Syarat dan Tata Cara Pelaksanaan Hak Warga Binaan Pemasyarakatan. Dalam peraturan pemerintah tersebut selanjutnya diatur, bahwa remisi bagi narapidana kasus korupsi dapat diberikan apabila memenuhi persyaratan sebagai berikut: ${ }^{28}$

1) Berkelakuan baik;

2) Telah menjalani $1 / 3$ masa pidana.

Dalam sebuah diskusi yang bertajuk "Moratorium dan Remisi Untuk Koruptor, Legal atau Melanggar Hukum", Yusril Ihza Mahendra mengemukakan, bahwa hak remisi ini diatur bukan hanya dalam undangundang tetapi juga konstitusi, konvensi PBB melawan korupsi ( $U N$ Convention Against Corruption), Tokyo Rules, dan sebagainya ${ }^{29}$

Yusril selanjutnya menyatakan, bahwa hak remisi ini dalam seluruh peraturan domestik dan internasional yang ada melekat pada narapidana. Sudah menjadi aturan di seluruh dunia, bahwa hukuman penjara dapat dikurangi atau dipercepat jika narapidana memiliki kelakuan baik.

Beberapa argumen yang dikemukakan oleh Yusril untuk mendukung pernyataannya adalah:

1) Indonesia bukan negara kekuasaan atau machtstaat, tetapi negara hukum atau rechtstaat, oleh karena itu kebijakan penghilangan remisi merupakan tindakan otoriter;

2) Penghilangan remisi melanggar HAM para terpidana korupsi yang berkelakuan baik setelah menjalani masa hukuman;

3) Sifat diskriminasi remisi, yang hanya dianggap dilakukan dalam hari raya keyakinan tertentu dan tidak di hari raya keyakinan yang lainnya;

4) Penghilangan remisi juga melanggar Konvensi PBB tentang korupsi;

${ }^{27}$ Bambang Widodo Umar, Op. Cit., hal. 20-21.

${ }^{28}$ Indonesia, Peraturan Pemerintah tentang Syarat dan Tata Cara Pelaksanaan Hak Warga Binaan Pemasyarakatan, PP Nomor 28 tahun 2006, Pasal 34 ayat (3).

29 Yusril Ihza Mahendra, Moratorium dan Remisi Untuk Koruptor, Legal atau Melanggar Hukum, Diskusi di Gedung DPR RI, Jakarta, Kamis 3 November 2011. 
5) Kebijakan remisi hanya sekedar politik citra, bukan motif murni penegakan hukum. ${ }^{30}$

Pendapat yang menolak penghapusan remisi bagi koruptor juga diungkapkan oleh Ketua Komisi Hak Asasi Manusia (Komnas HAM) Ifdhal Kasim yang menyatakan, bahwa remisi pada dasarnya merupakan insentif bagi terpidana untuk menstimulasikan agar merubah diri selama di penjara oleh karena secara normatif seorang terpidana sudah dirampas kebebasannya dengan menjalani hukuman penjara.

Namun setelah masuk ke dalam penjara, mereka tetap mempunyai hak minimal yaitu mendapatkan remisi dan/atau pembebasan bersyarat. Bila hak mendapatkan remisi dan/atau pembebasan bersyarat dicabut, secara otomatis haknya turut dirampas. Ini tidak dapat dibenarkan dengan alasan apapun juga. ${ }^{31}$

Pendapat lain yang menentang kebijakan pemberian remisi bagi koruptor diungkapkan oleh mantan Ketua Mahkamah Konstitusi Jimly Assidiqie yang menyatakan, bahwa: ${ }^{32}$

Kebijakan Pak Amir Syamsudin bisa dikatakan melanggar hukum, mungkin buru-buru atau mengejar harapan masyarakat. Niatnya sudah baik, cuma caranya perlu dievaluasi. Jangan sembrono, harus prosedural, datanya lengkap dan untuk perbaikan bukan cari popularitas.

\section{Moratorium Remisi Bagi Koruptor}

Banyak pihak yang mendukung penerbitan moratorium ${ }^{33}$ remisi bagi para koruptor. Roy Salam peneliti Indonesia Budget Center misalnya

30 Argumentum Ad Hominem, <http://www.yusril.ihzamahendra.com>, diakses Jumat 28 November 2014.

31 Pemerintah Akan Terbitkan Moratorium Remisi Bagi Koruptor, <http://www.voanews.com>, diakses Jumat 28 November 2014.

32 Problematika Pemberian Moratorium Remisi, <http://www.detiknews.com>, diakses Jumat 28 November 2014.

${ }^{33}$ Moratorium atau penghentian sementara pemberian remisi bagi para narapidana pelaku kejahatan terorganisir, khususnya korupsi dan terorisme, akan diatur melalui peraturan pelaksanaan teknis seperti Peraturan Pemerintah (PP). Pelaksanaan moratorium remisi tidak sampai diatur pada tingkatan undang-undang. Menurut Staf Khusus Presiden bidang Hukum dan Hak Asasi Manusia Denny Indrayana, PP memang mengatur hal-hal yang spesifik, seperti moratorium. Berbeda dengan undang-undang yang lebih mengarah pada aturan remisi secara umum."Tidak perlu sampai ke wilayah undang-undang, (moratorium) ini kan hanya untuk kasus tertentu saja," kata Denny ketika dihubungi, Jumat 16 September 2011. Sebelumnya, Denny mengatakan Presiden SBY menyepakati pelaku kejahatan terorganisasi, khususnya korupsi dan terorisme, diberi efek jera. Caranya adalah dengan menghentikan remisi bagi koruptor dan teroris. "Kebijakan moratorium remisi bagi tindak pidana korupsi dan terorisme itu dilakukan seiring dengan perbaikan peraturan perundangan yang mendasarinya agar lebih 
mengemukakan, bahwa pemerintah diminta segera merealisasikan kebijakan penghentian sementara (moratorium) pemberian remisi dan pembebasan bersyarat bagi koruptor. Roy selanjutnya mengemukakan, bahwa moratorium remisi dan pembebasan bersyarat bagi koruptor harus dikawal dan jangan sampai wacana ini keras awalnya saja, tetapi kempes di tengah jalan. Hanya sekedar pencitraan pemerintah saat ini ${ }^{34}$

Pendapat lain yang mendukung kebijakan moratorium remisi bagi koruptor juga disampaikan oleh Ketua Mahkamah Konstitusi Mahfud MD yang menyatakan, bahwa untuk jangka panjang, remisi dan pembebasan bersyarat bagi koruptor perlu dihapus melalui legislative review. ${ }^{35}$

Sebenarnya sebagian besar masyarakat mendukung kebijakan penghapusan remisi bagi koruptor, namun untuk memulainya tidak bisa dilaksanakan sekarang tetapi harus didahului dengan mengganti peraturan perundang-undangannya. Penggantian inilah yang belum dilakukan, sehingga kebijakan Menteri Hukum dan HAM yang menunda (moratorium) remisi terhadap pelaku korupsi menjadi kontroversial.

Dukungan juga diungkapkan oleh Komisi III DPR RI sebagaimana dinyatakan oleh Wakil Ketua Komisi III Tjatur Sapto Edy: ${ }^{36}$

\section{Komisi III DPR pada prinsipnya mendukung moratorium remisi bagi koruptor, namun remisi perlu dipatenkan dalam bentuk revisi UU Pemasyarakatan. Itu terserah Kemenhukham, kalau memang revisi UU mau dipercepat, DPR selalu terbuka. Bahkan Komisi III tidak mempermasalahkan jika semua remisi dihapuskan dengan tujuan agar semua orang jera melakukan kejahatan.}

Dalam keterangan persnya, Wakil Menteri Hukum dan HAM Denny Indrayana menyatakan: ${ }^{37}$

jelas dan sejalan dengan semangat antikorupsi," ujar Denny kemarin. Menurut Denny, moratorium akan diatur melalui PP agar mempermudah dan mempercepat prosesnya. Karena, jika moratorium diatur melalui undang-undang dan harus melalui revisi UU, maka dikhawatirkan akan berpengaruh terhadap kejahatan umum lainnya. Seperti diketahui, pemberian remisi atau pengurangan masa hukuman bagi narapidana diatur dalam UU Nomor 12 Tahun 1995 tentang Pemasyarakatan, khususnya Pasal 14 ayat (1). Adapun moratorium remisi ini akan dilakukan melalui revisi Peraturan Pemerintah nomor 28 Tahun 2006 tentang perubahan atas PP nomor 32 Tahun 1999, tentang Syarat dan Tata Cara Pelaksanaan Warga Binaan Pemasyarakatan. Peraturan ini menyinggung soal pengaturan remisi.lihat Moratorium Remisi, <http://www.tempo.co/.../Moratorium-Remisi-untuk-Koruptor-Diatur-Lewat-PP>, diakses 1 Desember 2014.

${ }^{34}$ Roy Salam, Segera Realisasikan Wacana Moratorium Remisi Bagi Koruptor, <http://www. berita.liputan6.com>, diakses 1 Desember 2014.

35 Mahfud MD., Pro Kontra Moratorium Bagi Koruptor, <http://www.antaranews.com>, diakses 1 Desember 2014.

36 Perlu Revisi UU Untuk Moratorium Remisi Koruptor, <http://www.bataviase.co.id>, diakses 1 Desember 2014. 
kebijakan yang diambilnya bersama Menhukham Amir Syamsudin terkait remisi terhadap koruptor merupakan bentuk perlawanan terhadap koruptor. Kebijakan tersebut berupa pengetatan remisi maupun pembebasan bersyarat bukanlah hal baru. Dalam PP Nomor 28 tahun 2006, sudah ada aturan menyangkut pengetatan remisi tersebut. Dalam hal ini hak narapidana untuk mendapatkan remisi dan pembebasan bersyarat dapat dikesampingkan sesuai konstitusi. Menurut UUD 1945, HAM ada yang dapat disimpangi dan ada yang tidak. Hak-hak narapidana untuk mendapatkan remisi dan pembebasan bersyarat merupakan hak yang disimpangi dengan menerapkan syarat dan pembatasan dalam peraturan

Deny Indrayana selanjutnya mengemukakan, bahwa Kementerian Hukum dan HAM melakukan moratorium pemberian remisi atau keringanan waktu hukuman untuk koruptor kecuali kepada koruptor yang membantu pengungkapan kasus-kasus korupsi yang lebih besar. Seperti Agus Condro masih bisa diberikan remisi karena banyak membantu KPK dan aparat penegak hukum dalam pengungkapan berbagai kasus korupsi yang besar.

Dalam masa transisi penegakan hukum, kebijakan pemerintah memperketat syarat remisi, bahkan menghapuskan sekalipun, tidak layak diperdebatkan dengan bersandar pada hak asasi koruptor. Perbuatan tercela yang dilakukan oleh koruptor telah merampas hak asasi rakyat banyak, sehingga harus diperlakukan luar biasa dalam proses hukumnya, yang tidak hanya selesai saat hakim menjatuhkan putusan. Keluarbiasaan tersebut harus sampai pada pelaksanaan putusan dalam lembaga pemasyarakatan, agar koruptor menyadari kesalahan.

Pelaksanaan hukuman di lembaga pemasyarakatan adalah bagian dari proses bekerjanya criminal justice system, dan tidak berarti telah selesai saat hakim menjatuhkan putusannya. Memperketat bahkan menghapuskan remisi bagi koruptor, pada hakikatnya merupakan keniscayaan sebagai kebijakan progresif terhadap perbuatan korupsi. Dalam merespon fenomena sosial yang berkembang saat ini termasuk korupsi, hukum Indonesia harus menunjukkan keberadaan dan wataknya sesuai dengan perkembangan dan kompleksitas interaksi nasional maupun internasional.

Adanya pro kontra di dalam masyarakat tentang moratorium remisi bagi para koruptor, pada prinsipnya menunjukkan adanya kesenjangan antara hukum secara normatif (das sollen) dan hukum secara sosiologis

37 Pemerintah Akan Terbitkan Moratorium Remisi Bagi Koruptor, <http://www.kompasnews.com>, diakses 1 Desember 2014. 
(das sein) atau kesenjangan antara perilaku hukum masyarakat yang seharusnya dan perilaku kelembagaan hukum yang semestinya.

Banyak pihak yang kecewa dan sakit hati melihat ringannya hukuman yang dijatuhkan oleh hakim bagi pelaku korupsi. Kekecewaan dan sakit hati tersebut bertambah besar manakala mendengar, bahwa terpidana kasus korupsi mendapat perlakuan dan fasilitas yang sangat istimewa di dalam penjara.

Dalam kaidah hukum secara tegas dinyatakan, bahwa semua manusia mempunyai kedudukan yang sama di hadapan hukum (equality before the law). Hal ini berarti tidak ada perbedaan antara subjek hukum yang satu dengan subjek hukum yang lain di hadapan hukum. ${ }^{38}$

Prinsip persamaan kedudukan manusia di hadapan hukum ini bukan hanya merupakan prinsip hukum yang paling mendasar tetapi juga merupakan prinsip keadilan. Hak untuk memperoleh keadilan merupakan salah satu hak dasar manusia, karena hak itu terkait langsung dengan harkat dan martabat manusia. Keadilan hanya dapat ditegakkan apabila ada perlakuan yang sama bagi setiap orang yang mempunyai kondisi yang sama. ${ }^{39}$

Menanggapi berkembangnya pro dan kontra berkaitan dengan rencana moratorium remisi bagi koruptor, Satjipto Rahardjo yang mengutip pendapat Chambliss dan Seidmann berpendapat, bahwa dalam kacamata sosiologi hukum, undang-undang, aturan, doktrin dan fiksi hukum itu sering dianggap sebagai mitos-mitos dalam hukum yang dibuktikan kebohongannya dalam kehidupan hukum sehari-hari. ${ }^{40}$

Maksud dari penggunaan istilah 'mitos' di sini adalah pendapat orang yang menganggap bahwa hukum itu dilaksanakan persis seperti yang tertulis dalam undang-undang. Kenyataannya antara yang tertulis itu dengan realitasnya sering terdapat perbedaan yang besar. Dengan demikian pengkajian hukum yang cermat dan seksama tidak dapat mengabaikan faktor manusianya.

Mempertimbangkan faktor manusia dalam kajian hukum menjadi amat penting. Hal tersebut dapat dilihat dari pendapat Chambliss dan Seidman. $^{41}$ Menurut kedua ahli ini, model pembuatan hukum dalam masyarakat dapat dibedakan atas dua model, yaitu:

${ }^{38}$ Nathieu Deflem, "Sociological Theories of Law", in "Encyclopedia of Law and Society: American and Global Perspectives”, Edited by David S. Clark, (California: Thousand Oaks, 2007), p. 1410-1413.

${ }^{39}$ Soerjono Soekanto, "Pokok-pokok Sosiologi Hukum", (Jakarta: Raya Grafindo Persada, 1994), hal. 32.

${ }^{40}$ Satjipto Rahardjo "Masalah Penegakan Hukum”, (Bandung: Sinar Baru, tt), hal. 6.

${ }^{41}$ Robert B. Seidman \& William J. Chambles, "Law, Order, and Power”, Printed in United States of America, Pubhlised Stimulant Costly in Canada Library of Congress Catalog Card No. 78-111948, p. 1972. 
1) Model Kesepakatan Nilai-nilai (value consensus). Bahwa pembuatan Hukum adalah menetapkan nilai-nilai yang berlaku dalam masyarakat. Pembuatan hukum merupakan pencerminan nilai-nilai yang disepakati oleh warga masyarakat.

2) Model Masyarakat konflik. Bahwa pembuatan Hukum dilihat sebagai proses adu kekuatan, negara merupakan senjata di tangan lapisan masyarakat yang berkuasa. Sekalipun terdapat pertentangan nilai-nilai, Negara tetap dapat berdiri sebagai badan tidak memihak (value-neutral).

Teori yang digunakan untuk melakukan analisis teoritis tentang pembentukan hukum dan implementasinya (tentang bekerjanya hukum) didayagunakan untuk melakukan analisis tentang pembentukan hukum sekaligus juga untuk melakukan analisis terhadap implementasi hukum.

Menurut teori ini, pembentukan hukum dan implementasinya tidak akan lepas dari pengaruh atau asupan kekuatan-kekuatan sosial dan personal, terutama pengaruh atau asupan kekuatan sosial politik. Itulah sebabnya kualitas dan karakter hukum juga tidak lepas dari pengaruh bekerjanya kekuatan-kekuatan dan personal tersebut terutama kekuatankekuatan politik pada saat hukum itu dibentuk.

Dari model bekerjanya hukum tersebut, oleh Seidman dirumuskan beberapa pernyataan teoretis sebagai berikut:

1) Setiap peraturan hukum itu menunjukkan aturan-aturan tentang bagaimana seseorang pemegang peran diharapkan untuk bertindak;

2) Tindakan apa yang akan diambil oleh seseorang pemegang peran sebagai respons terhadap peraturan hukum, sangat tergantung dan dikendalikan oleh peraturan hukum yang berlaku, dari sanksi-sanksinya, dari aktivitas lembaga pelaksanaannya, serta dari seluruh kompleks kekuatan sosial, politik, dan lain sebagainya yang bekerja atas dirinya;

3) Tindakan apa yang akan diambil oleh lembaga pelaksana sebagai respons terhadap peraturan-peraturan hukum, sangat tergantung dan dikendalikan oleh peraturan hukum yang berlaku, dari sanksi-sanksinya, dan dari seluruh kompleks kekuatan sosial, politik, dan lain sebagainya yang bekerja atas dirinya, serta dari umpan balik yang datang dari pemegang peran dan birokrasi;

Tindakan apa yang akan diambil oleh lembaga pembuat undangundang sebagai respons terhadap peraturan hukum, sangat tergantung dan dikendalikan oleh berfungsinya peraturan hukum yang berlaku, dari sanksi-saksinya, dan dari seluruh kompleks kekuatan sosial, politik, dan lain sebagainya yang bekerja atas mereka, serta dari umpan balik yang datang dari pemegang peran dan birokrasi.

Dengan demikian, hukum dan politik yang berpengaruh dan tak dapat dipisahkan dari hukum yang bekerja di dalam masyarakat. Bahwa 
hukum itu untuk masyarakat, sebagaimana teori living law. Fungsi-fungsi hukum hanya mungkin dilaksanakan secara optimal, jika hukum memiliki kekuasaan dan ditunjang oleh kekuasaan politik.

Meskipun kekuasaan politik memiliki karakteristik tidak ingin dibatasi, sebaliknya hukum memiliki karakteristik untuk membatasi segala sesuatu melalui aturan-aturannya. Hal tersebut dilakukan dalam rangka mencegah timbulnya penyalahgunaan kekuasaan dan kesewenang-wenangan. Sebaliknya kekuasaan politik menunjang terwujudnya fungsi hukum dengan 'menyuntikan' kekuasaan pada hukum, yaitu dalam wujud sanksi hukum.

Legitimasi hukum melalui kekuasaan politik, salah satunya terwujud dalam pemberian sanksi bagi pelanggar hukum. Sekalipun demikian, jika sudah menjadi hukum, maka politik harus tunduk kepada hukum, bukan sebaliknya.

Demikian konsekuensi dari Pasal 1 ayat (3) Undang-Undang Dasar Negara Republik Indonesia Tahun 1945 bahwa "Negara Indonesia adalah Negara Hukum". Demikian hukum dan politik saling bergantung dan berhubungan satu sama lainnya, dan saling mendukung ketika hukum bekerja dalam masyarakat, sebagaimana teori Chambliss dan Seidman.

Dengan tujuan supaya di masa mendatang tidak terjadi lagi perbedaan pendapat yang berpotensi melahirkan konflik horizontal maupun vertikal, perlu ada pembangunan hukum. Model hukum di Indonesia saat ini yang bersifat teknokratis struktural tidak cukup lagi untuk membawa Indonesia ke masa depan dengan struktur sosial yang beragam dan pelapisan sosial yang beragam pula.Keragaman yang dimiliki Indonesia tidak cukup apabila hanya dijembatani dengan regulasi negara yang sifatnya sentralistik. Sudah saatnya bangsa Indonesia melakukan pergeseran paradigma hukum dan juga pembangunan hukum, dari yang teknokratis struktural ke arah yang humanis partisipatoris.

Model hukum yang humanis partisipatoris dibangun sebagai hasil dialektika terhadap fungsi-fungsi hukum sebagai sarana rekayasa dan kontrol sosial maupun sebagai sarana mekanisme integrasi. Ketiga fungsi hukum tersebut sangat mempengaruhi kebijakan pemerintah Indonesia dalam segala aspek kehidupan.

Fungsi hukum yang humanis partisipatoris merupakan perwujudan dari hukum yang mendasarkan pada martabat manusia dan nilai-nilai kemanusiaan melalui pemberian prakarsa dan kesempatan kepada masyarakat dalam proses pengambilan keputusan untuk memenuhi kebutuhan hidup manusia. Wajah hukum yang humanis partisipatoris ini baru akan menampakkan wujudnya apabila negara memberikan perhatian pada aspek dan dimensi manusiawi sebagai tujuan utama pembangunan, yang memberikan akses kepada warganegara untuk ikut serta dalam pengambilan keputusan dalam berbagai bidang kehidupan.

Konsep yang diberikan adalah bagaimana hukum mampu memberikan daya/kekuatan tawar menawar kepada warganegara, 
sehingga mampu menempatkan posisinya secara mandiri. Apabila kondisi yang demikian terwujud, maka arah pemberdayaan sosial mulai menampakkan titik terang.

Fungsi hukum sebagai sarana pemberdayaan sosial pada hakikatnya adalah memberikan alokasi wewenang yang lebih besar kepada warganegara untuk menentukan realisasi dirinya sebagai subjek dalam kehidupan. Bukan sebagai objek yang hendak dibentuk atau dikontrol oleh subjek lain yang dominan. Dengan model hukum humanis partisipatoris, diharapkan perbedaan pendapat atau pro kontra antara berbagai elemen masyarakat yang sering terjadi apabila penguasa (pemerintah) menerbitkan suatu kebijakan (termasuk moratorium remisi bagi koruptor) dapat diminimalisasi dan bahkan dihilangkan sama sekali.

Haruslah disadari benar bahwa upaya menegakan hukum tidaklah semudah membalik telapak tangan. Kejadian-kejadian yang sekarang menimpa lembaga hukum hanyalah satu proses untuk menuju terciptanya wibawa hukum ${ }^{42}$. Sikap mawas diri merupakan langkah terpuji yang seyogyanya dibarengi dengan upaya-upaya yang bersifat sistemik dari Lembaga-lembaga hukum mulai dari kejaksaan, kepolisian, kehakiman dan organisasi penasehat hukum.

Sudah saatnya lembaga-lembaga penegak hukum melakukan:

Pertama, evaluasi berkesinambungan atas semua program dan kebijaksanaan yang sudah dicanangkan, agar dapat mengurangi kendala yang dihadapi,

Kedua, klarifikasi kasus-kasus besar yang diputus oleh pengadilan, sehingga masyarakat mengetahui secara jelas pertimbangan hukum dan dasar-dasar hukum yang digunakan.

Ketiga adalah reorientasi visi dan misi lembaga penegak hukum agar mengutamakan keadilan substansial.

\section{Penutup}

\section{Kesimpulan}

1. Korupsi adalah kejahatan kriminal luar biasa (extra ordinary crime), bahkan, United Nations Convention Against Corruption (UNCAC) mengklasifikasikan korupsi sebagai kejahatan hak asasi manusia (human rights crime) dan kejahatan kemanusiaan (crime against humanity). Koruptor harusnya diberi hukuman maksimal, tanpa remisi. Mereka sudah mengeruk uang negara yang menimbulkan kerugian bagi jutaan rakyat, sehingga tidak pantas

${ }^{42}$ Esmi Warasih, Pemberdayaan Masyarakat Dalam Mewujudkan Tujuan Hukum. Proses Penegakan Hukum dan Persoalan Keadilan, Pidato pengukuhan Guru Besar, UNDIP 14 April 2001. 
mendapat keistimewaan. Justru koruptor harusnya dimiskinkan dan kalau perlu diberi sanksi sosial. Memang penjara bukanlah tempat untuk balas dendam. Namun, penjara juga bukan tempat seorang penjahat boleh menikmati keistimewaan termasuk mendapat remisi. Menghukum seseorang koruptor secara maksimal bukan hanya pembelajaran bagi terpidana itu sendiri, melainkan juga menjadi pelajaran bagi jutaan orang di luar tembok penjara agar mengurungkan niat merampok uang negara. Penghapusan dan/atau memperketat pemberian remisi bagi koruptor merupakan kebijakan yang layak untuk diterapkan. Alasan kelakuan baik selama berada di penjara tidak dapat digunakan untuk memberikan remisi. Betapapun para koruptor memperlihatkan kelakuan baik selama di penjara, alasan tersebut tidak dapat menghapus kejahatan korupsi yang telah dilakukannya. Apalagi biasanya motif mereka berkelakuan baik di penjara hanya untuk memperoleh remisi.

2. Adanya pro kontra di dalam masyarakat tentang moratorium remisi bagi para koruptor, pada prinsipnya menunjukkan adanya kesenjangan antara hukum secara normatif (das sollen) dan hukum secara sosiologis (das sein) atau kesenjangan antara perilaku hukum masyarakat yang seharusnya dan perilaku kelembagaan hukum yang semestinya. Banyak pihak yang kecewa dan sakit hati melihat ringannya hukuman yang dijatuhkan oleh hakim bagi pelaku korupsi. Kekecewaan dan sakit hati tersebut bertambah besar manakala mendengar, bahwa terpidana kasus korupsi mendapat perlakuan dan fasilitas yang sangat istimewa di dalam penjara. Dalam masa transisi penegakan hukum, kebijakan pemerintah memperketat syarat remisi, bahkan menghapuskan sekalipun, tidak layak diperdebatkan dengan bersandar pada hak asasi koruptor. Perbuatan tercela yang dilakukan oleh koruptor telah merampas hak asasi rakyat banyak, sehingga harus diperlakukan luar biasa dalam proses hukumnya, yang tidak hanya selesai saat hakim menjatuhkan putusan. Keluarbiasaan tersebut harus sampai pada pelaksanaan putusan dalam lembaga pemasyarakatan, agar koruptor menyadari kesalahan. Menanggapi berkembangnya pro dan kontra berkaitan dengan rencana moratorium remisi bagi koruptor, Satjipto Rahardjo yang mengutip pendapat Chambliss dan Seidmann berpendapat, bahwa dalam kacamata sosiologi hukum, undang-undang, aturan, doktrin dan fiksi hukum itu sering dianggap sebagai mitos-mitos dalam hukum yang dibuktikan kebohongannya dalam kehidupan hukum seharihari. 


\section{Saran}

1. Seharusnya pemerintah bukan hanya memberlakukan moratorium atau penghapusan remisi bagi para koruptor, akan tetapi juga untuk jangka panjang Undang Undang Pemasyarakatan perlu direvisi.

2. Agar pemerintah lebih ketat dalam melakukan pengawasan di lembaga pemasyarakatan untuk menghindari pemberian fasilitas khusus bagi narapidana kasus korupsi.

3. Mahmakah Agung dan Jaksa Agung perlu menekankan agar Jaksa Penuntut Umum dan Hakim yang menangani kasus korupsi, tidak kompromi dengan koruptor.

4. Jika terbukti bersalah, Jaksa Penuntut Umum harus menuntut koruptor hukuman maksimal sesuai ketentuan pidana yang berlaku dan kemudian Hakim memvonisnya sejalan dengan rasa keadilan masyarakat .

5. Tindakan untuk memiskinkan koruptor agar menjadi salah satu agenda penegakan hukum yang melibatkan terpidana koruptor dengan jalan menyita seluruh aset yang diduga berasal dari hasil korupsi selama proses penyelidikan, penyidikan dan pengadilan berlangsung. 


\section{Daftar Pustaka}

\section{Buku}

Ali, Zainuddin. Sosiologi Hukum, Cetakan Kelima. Jakarta: Sinar Grafika, 2009.

Banakar, R., and M. Travers. Law, Sociology and Method in Theory and Method in Sosio Legal Research, Oxford: Hart Publishing, 2005.

Cotterrell, Roger. Law, Culture and Society: Legal Ideas in the Mirror of Social Theory, Aldershot: Ashgate, 2007.

Deflem, Nathieu. Sociological Theories of Law. In Encyclopedia of Law and Society: American and Global Perspectives, Edited by David S. Clark. California: Thousand Oaks, 2007.

Fakrulloh, Zudan Arif. Ilmu Lembaga dan Pranata Hukum, Jakarta: Raja Grafindo Persada, 2009.

Friedman, L.M. The Legal System: A Social Science Perspective, New York: Russell Sage Foundation, 1975. 1986.

Glaeser, Edward L., and Claudia Goldin, eds, Corruption and Reform: Lessons from America's Economic History, University of Chicago Press, 2006.

Hunt, Alan. Explorations in Law and Society, New York : Routledge, 1993.

Johnson, Alvin S. Sosiologi Hukum, Jakarta: Penerbit Rineka Cipta, 2007.

Munger, Frank. Mapping Law and Society, Northwestern University Press, 1998.

Nonet, Philippe and Philip Selznick. Law and Society in Transition: Toward Responsive Law, New York: Octagon Books, 1978.

Rahardjo, Satjipto. Masalah Penegakan Hukum, Bandung: Sinar Baru, tt.

Podgorecki, Adam, dan Christopher J. Whelan. Pendekatan Sosiologi Terhadap Hukum, Jakarta: Bina Aksara, 1987.

Podgorecki, Adam. A Sociological Theory of Law, Milano: Dott A. Giuffre Editore, 1995.

Soekanto, Soerjono. Pokok-pokok Sosiologi Hukum, Jakarta: Raya Grafindo Persada, 1994.

Umar, Bambang Widodo. Paradigma Sosiologi Hukum. Jakarta: Universitas Indonesia, 2009. 
Warasih, Esmi. Pemberdayaan Masyarakat Dalam Mewujudkan Tujuan Hukum. Proses Penegakan Hukum dan Persoalan Keadilan, Pidato pengukuhan Guru Besar, UNDIP 14 April 2001.

\section{Artikel/Makalah/Jurnal}

Mahendra, Yusril Ihza. "Moratorium dan Remisi Untuk Koruptor, Legal atau Melanggar Hukum”, Diskusi di Gedung DPR RI, Jakarta, Kamis 3 November 2011.

Mahfud MD. "Pro Kontra Moratorium Bagi Koruptor", <http://www.antaranews.com>, diakses 1 Desember 2014.

Revida, Erika. "Korupsi Di Indonesia: Masalah dan Solusinya”. Makalah, Fakultas Ilmu Sosial dan Ilmu Politik Universitas Sumatera Utara. Medan, 2003.

Salam, Roy. "Segera Realisasikan Wacana Moratorium Remisi Bagi Koruptor”, <http://www.berita.liputan6.com>, diakses 1 Desember 2013.

"Argumentum Ad Hominem", <http://www.yusril.ihzamahendra.com>, diakses 28 November 2013.

"Kemenkum HAM Berlakukan Moratorium Remisi Bagi Koruptor", <http://www.berita. liputan6.com>, diakses 1 Desember 2013.

"KPK Rekomendasikan Tak Berikan Remisi Bagi Koruptor", <http://www.kpk.com>, Diakses Kamis 20 November 2013.

"KPK Kecewa Kementerian Hukum Obral Remisi Bagi Koruptor", <http://www.tempo.com>, Diakses Kamis 20 November 2014

"Moratorium Remisi Terhadap Koruptor Jangan Hanya Wacana", <http://www.news.okezone.com/read/2011/10/31/339/523022/ moratorium.>, diakses 1 Desember 2013.

"Penghapusan Remisi Bagi Koruptor Belum Cukup", <http://www.nasional.kompas.com>, diakses 20 November 2013.

"Pemberian Remisi Untuk Koruptor Diperketat", <http://www.metrotvnews.com>, diakses 1 esember 2013.

"Pemberlakuan Moratorium Remisi Bagi Pelaku Tindak Pidana Korupsi", <http://www.arya-sosman.blogspot.com>, diakses 28 November 2014.

"Pemerintah Akan Terbitkan Moratorium Remisi Bagi Koruptor", <http://www.voanews.com>, diakses 1 Desember 2013.

"Pemerintah Akan Terbitkan Moratorium Remisi Bagi Koruptor", <http://www.kompasnews. com>, diakses 1 Desember 2013.

"Perlu Revisi UU Untuk Moratorium Remisi Koruptor", <http://www.bataviase.co.id>, diakses 1 Desember 2013. 
"Problematika Pemberian Moratorium Remisi", <http://www.detiknews.com>, diakses 28 November 2014.

"Remisi Untuk Koruptor?", <http://www.ocemadril.wordpress.com>, diakses 28 November 2014.

"Tiga Koruptor Diusulkan Dapat Remisi”, <https://www.id.berita.yahoo.com/ tiga-koruptor-ini-diusulkan-dapat-remisi-lagi>, diakses Kamis 20 November 2014.

"Upaya Pemberantasan Korupsi", <http//www.lampung-news.com/article/ opini>, Diakses 1 Desember 2014.

\section{Peraturan Perundang-undangan}

Undang Undang tentang Pemasyarakatan. UU RI Nomor 28 tahun 2006.

Peraturan Pemerintah tentang Syarat dan Tata Cara Pelaksanaan Hak Warga Binaan Pemasyarakatan. PP Nomor 28 tahun 2006. 